\title{
Reduction of erythroid progenitors in protein-energy malnutrition
}

\author{
Primavera Borelli ${ }^{1}$, Solange Blatt ${ }^{1}$, Juliana Pereira ${ }^{2}$, Beatriz Beutler de Maurino ${ }^{2}$, Maristela Tsujita ${ }^{2}$, \\ Ana Cristina de Souza ${ }^{1}$, José Guilherme Xavier ${ }^{3}$ and Ricardo Ambrósio Fock ${ }^{1}$ \\ ${ }^{1}$ Laboratório Hematologia Experimental, Departmento de Análises Clínicas e Toxicológicas, Faculdade de Ciências \\ Farmacêuticas, Universidade de São Paulo, Brazil \\ ${ }^{2}$ Laboratório Imunopatologia, Disciplina de Hematologia do Hospital das Clínicas da Faculdade de Medicina da \\ Universidade de São Paulo, Brazil \\ ${ }^{3}$ Faculdade de Medicina Veterinária, Instituto de Ciências da Saúde, Universidade Paulista, São Paulo, Brazil
}

(Received 31 August 2005 - Revised 4 May 2006 - Accepted 4 May 2006)

\begin{abstract}
Protein-energy malnutrition is a syndrome in which anaemia together with multivitamin and mineral deficiency may be present. The pathophysiological mechanisms involved have not, however, yet been completely elucidated. The aim of the present study was to evaluate the pathophysiological processes that occur in this anaemia in animals that were submitted to protein-energy malnutrition, in particular with respect to Fe concentration and the proliferative activity of haemopoietic cells. For this, histological, histochemical, cell culture and immunophenotyping techniques were used. Two-month-old male Swiss mice were submitted to protein-energy malnutrition with a low-protein diet (20 g/kg) compared with control diet $(400 \mathrm{~g} / \mathrm{kg})$. When the experimental group had attained a $20 \%$ loss of their original body weight, the animals from both groups received, intravenously, $20 \mathrm{IU}$ erythropoietin every other day for $14 \mathrm{~d}$. Malnourished animals showed a decrease in red blood cells, Hb concentration and reticulocytopenia, as well as severe bone marrow and splenic atrophy. The results for serum Fe, total Fe-binding capacity, transferrin and erythropoietin in malnourished animals were no different from those of the control animals. Fe reserves in the spleen, liver and bone marrow were found to be greater in the malnourished animals. The mixed colony-forming unit assays revealed a smaller production of granulocyte-macrophage colony-forming units, erythroid burst-forming units, erythroid colony-forming units and CD45, CD117, CD119 and CD71 expression in the bone marrow and spleen cells of malnourished animals. These findings suggest that, in this protein-energy malnutrition model, anaemia is not caused by Fe deficiency or erythropoietin deficiency, but is a result of ineffective erythropoiesis.
\end{abstract}

Erythropoiesis: Anaemia: Protein malnourishment

Protein malnutrition continues to represent a significant world health problem, especially with regard to children, the elderly and those in hospital. Nutritional deficiencies can result in an impairment of cognitive function as well of overall development and motor coordination, and are associated with an increase in morbidity following infectious diseases (Lozoff et al. 1991).

Protein-energy malnutrition is a syndrome in which anaemia may be present. Anaemia has multiple aetiologies: it can be caused by congenital abnormalities or be associated with several diseases, such as chronic renal disease or even other nutritional alterations. Literature describes the frequent occurrence of anaemia in malnutrition, which can be due to Fe and folate deficiency (Macdougall et al. 1982; Villalpando et al. 2003; Gasche et al. 2004; Moretti et al. 2004), vitamin A deficiency, protein deficiency, a decrease in erythropoietin level (Stenvinkel, 2003; Gibson, 2004), haemolysis due to an alteration in the antioxidant mechanisms in erythrocytes, infection and (in tropical regions) infestation with parasites
(Buitron et al. 2004; Stoltzfus et al. 2004). Fe deficiency has been considered to be the main cause of this anaemia (Yip, 1996; Akman et al. 2004; Khosrof-Ben Jaafar et al. 2004; Mehta, 2004).

It is generally recognised that the aetiology of malnutrition is multifactorial, but the contribution of each nutritional factor to the establishment of several syndromes associated with malnutrition is not yet fully understood. Haemopoietic tissues, as with all those with a high rate of renewal and turnover, present a high demand for nutrients. The need for protein for haemopoiesis, particularly for erythropoiesis, could alone justify the occurrence of anaemia frequently observed in cases of malnutrition.

In our studies, we have observed that malnourished animals present with anaemia, even when the purified diet used contains a balanced content of vitamins and minerals, including Fe (Borelli et al. 1995). The aim of the present study was thus to evaluate erythropoiesis in a murine model of protein-energy malnutrition.

Abbreviations: CFU-MIX, mixed colony-forming units; EPO, erythropoietin.

* Corresponding author: Dr Primavera Borelli, fax +5511 3813 2197, email borelli@usp.br 


\section{Materials and methods}

\section{Diets}

The murine diets were prepared in our laboratories. Their diet contained fibre, saline mixtures and balanced vitamin mixtures in the same quantity, although the control purified diet contained $400 \mathrm{~g} / \mathrm{kg}$ protein and the hypoproteic purified diet only $20 \mathrm{~g} / \mathrm{kg}$ (Fried et al. 1978; Borelli et al. 1995). The source of protein used was casein. Except for the protein content, the two diets were identical and isocaloric (Table 1). The final protein content was monitored by the standard microKjeldahl method (Ward, 1963).

\section{Animals}

Male outbred Swiss mice of 2-3 months of age were obtained from the Faculty of Pharmaceutical Sciences at the University of São Paulo. They were placed in individual 'metabolic cages' and received the control diet for $21 \mathrm{~d}$. After this period of adaptation, the mice reached a stable body weight. They were subsequently divided into four groups (control, control + erythropoietin (EPO), malnourished and malnourished + EPO) maintained under a regular light/dark cycle of $12 \mathrm{~h}$, a temperature of $22-25^{\circ} \mathrm{C}$ and a humidity of $55 \%$, receiving either the control or the low-protein diet and water ad libitum. Their body weight was monitored every $72 \mathrm{~h}$ and the consumption of food every $48 \mathrm{~h}$.

Mice were submitted to experimental assays after $14 \mathrm{~d}$ of eating their respective chows, when the undernourished group had suffered about a $20 \%$ loss of their original body weight (Borelli et al. 1995). To collect the different biological samples, the animals were anaesthetised with xylazene chlorohydrate (Rompum, $10 \mathrm{mg} / \mathrm{kg}$; Bayer, Leverkusen, Germany) and with ketamide chlorohydrate (Ketamina, $100 \mathrm{mg} / \mathrm{kg}$; Cristália, Campinas, Brazil). This study was approved by the Commission for Ethics of Animal Studies of the Faculty of Pharmaceutical Sciences at the University of São Paulo.

\section{Erythropoietin}

Recombinant human erythropoietin (Cristália) was diluted in a pyrogen-free isotonic solution, distributed into aliquots and stored at $-40^{\circ} \mathrm{C}$ until used. Animals from the two EPO groups (control + EPO, malnourished + EPO) received $20 \mathrm{IU}$ EPO

Table 1. Composition of the experimental diets*

\begin{tabular}{lcc}
\hline & $\begin{array}{c}\text { Control diet } \\
(\mathrm{g} / \mathrm{kg} \text { diet })\end{array}$ & $\begin{array}{c}\text { Malnourishment diet } \\
(\mathrm{g} / \mathrm{kg} \text { diet })\end{array}$ \\
\hline Casein (>85\% protein) & 200 & 40 \\
Sucrose & 100 & 100 \\
Fibre & 10 & 10 \\
Corn oil & 80 & 80 \\
Mineral mixture $\dagger$ & 40 & 40 \\
Vitamin mixture† & 10 & 10 \\
L-Methionine & 1.5 & 1.5 \\
Choline bitartrate & 2.5 & 2.5 \\
Cornstarch & 556.5 & 716.5 \\
\hline
\end{tabular}

*Isocaloric diets providing $1716 \cdot 3 \mathrm{~kJ} / 100 \mathrm{~g}(410.6 \mathrm{kcal} / 100 \mathrm{~g})$.

† Mineral and vitamin mixtures were prepared according to the 1993 recommendations of the American Institute of Nutrition for adult mice (Reeves et al. 1993). intravenously every other day for 14 d (Silver \& Piver, 1999) during the malnutrition phase.

\section{Blood}

Animals were anaesthetised, and whole-blood samples with and without EDTA $(1 \mathrm{mg} / \mathrm{ml})$ were obtained via cardiac puncture. Bone marrow cells, sternum, liver and spleen were collected concomitantly with the blood from the animals that had or had not received EPO. Total and differential counts of blood cells were carried out (Dacie \& Lewis, 1995). The serum was separated by centrifugation, and the total protein content and albumin were determined by standard methods used in medical analysis (Gornall et al. 1949; Rodkey, 1965; Doumas et al. 1971).

\section{Determination of serum erythropoietin}

The quantification of erythropoietin present in serum was carried out by ELISA using commercial reagents (Quantikine M murine; R\&D Systems, USA) according to the manufacturer's instructions. The serum was separated by centrifugation ( $2000 \mathrm{~g}$ for $10 \mathrm{~min}$ at $4^{\circ} \mathrm{C}$ ) and frozen in aliquots at $-40^{\circ} \mathrm{C}$ until use. All samples were processed in duplicate.

\section{Determination of serum $\mathrm{Fe}$ and total Fe-binding capacity}

Blood samples obtained without anticoagulant were collected in demineralised containers, and serum Fe concentration as well as total Fe binding capacity (TIBC) and transferrin saturation were determined using the COBAS MIRA plus (Roche, Schweiz, Switzerland) automated system (Goodwin et al. 1966).

Bone marrow, spleen and liver: histology and evaluation of tissue $\mathrm{Fe}$

The sternum, spleen and liver were removed and immediately immersed in Carnoy fixative for $1 \mathrm{~h}$ and processed by standard histological techniques (paraffin-embedding). Sections measuring $5 \mu \mathrm{m}$ from sternum, liver and spleen were stained by haematoxylin and eosin and by the Perls method for the evaluation of tissue Fe (Rosai, 1996), and were evaluated by conventional optical microscopy. All material used was previously demineralised.

\section{Splenic cellularity}

The spleen was aseptically removed, placed in a $60 \mathrm{~mm}$ Petri dish (Corning Acton, MA, USA) containing Ca-free and $\mathrm{Mg}$ free phosphate buffer solution with EDTA $(1 \mathrm{mg} / \mathrm{ml}$; Sigma Chemical Co., St Louis, MO, USA) and gently dissociated. The total number of cells was quantified in a standard haemocytometer (Neubauer ${ }^{\circledR}$ chamber; Herka, Berlin, Germany). Cytocentrifuge smears were stained using standard May-Grunwald and Giemsa solutions (Sigma Chemical Co). Differential cell counts were performed considering 300 cells per slide.

\section{Bone marrow cellularity}

For the cell preparations, femurs were removed aseptically. Bone marrow cells were flushed from these using Fisher 
medium (Sigma Chemical Co.) supplemented with $10 \%$ fetal calf serum (Cultilab, Campinas, Brazil) and heparin $50 \mathrm{U}$ (Liquemine; Roche), and were used in a myelogram as well as in clonogenic assays and flow cytometry. Total cell counts were carried out, followed by differential counts on cytocentrifuge smears prepared as described above.

\section{Analysis of mixed colony-forming units}

The mixed colony-forming unit (CFU-MIX) assays were carried out according to the procedures of Heyworth \& Spooncer (1993) to evaluate the number of haemopoietic progenitors in the sample. Bone marrow cells were harvested and plated $\left(5 \times 10^{5}\right.$ cells $\left./ \mathrm{ml}\right)$ in triplicate into $35 \mathrm{~mm}$ Petri dishes (Nunc, Roskilde, Denmark) with methylcellulose medium (4000 $\mathrm{Kg} \mathrm{F} \mathrm{n}^{-1} \mathrm{~s}^{-1}$; Fischer, NJ, USA), $10 \%$ fetal calf serum (Gibco, Grand Island, NY, USA), $1 \%$ bovine serum albumin (Boehringer Mannheim, IN, USA), $10^{-4} \mathrm{M}$-methylprednisolone (Abbott, Brazil), $10^{-2} \mathrm{M}$-2-mercaptoethanol (Gibco), $0 \cdot 2 \mathrm{ng} / \mathrm{ml}$ recombinant murine granulocytemacrophage colony-stimulating factor (Sigma Chemical Co.), $0 \cdot 2 \mathrm{ng} / \mathrm{ml}$ recombinant murine granulocyte colony-stimulating factor (Sigma Chemical Co.), 1 IU recombinant human EPO (Cristália) and $0 \cdot 1 \mathrm{ng} / \mathrm{ml}$ interleukin-3 (Sigma Chemical Co.).

Cells were incubated in a humidified atmosphere of $95 \%$ air and $5 \% \mathrm{CO}_{2}$ at $37^{\circ} \mathrm{C}$ for $21 \mathrm{~d}$. Internal negative controls were made containing only the culture medium and cells. The number of clusters and colonies (Chimelli et al. 1994) was evaluated on the seventh, fourteenth and twenty-first days after culturing using an inverted microscope. Total cell counts were monitored, and differential counts were carried out on cytocentrifuge smears prepared as described above. Only viable cells with normal morphology were counted, whereas those with pyknotic nuclei and signs of degeneration were discarded.

Flow cytometric profiling of cells in the bone marrow and mixed colony-forming unit growth

Flow cytometry was used to determine the fraction of bone marrow and CFU-MIX growth cells positively labelled with antibodies against CD45 (LY-5, clone 30-F11), CD34 (clone RAM 34), Ter-119 (clone C55BL), CD71 (clone C2), CD117 (clone 2 B8) and CD2 (clone RM2-5) acquired from Becton Dickinson Pharmigen (San Diego, CA). Antibodies to Ter-119 and CD71 were conjugated with phycoerythrin; anti-CD45, anti-CD34, anti-CD117 and anti-CD2 were conjugated with fluorescein isothiocyanate. The isotype controls were rat immunoglobulins 2a kappa, fluorescein isothiocyanate (clone R35-95), for CD34; immunoglobulin G2b kappa, fluorescein isothiocyanate (clone A95-1), for CD45, CD117 and CD2;:immunoglobulins G1 kappa, phycoerythrin, for CD71 and Ter-119.

For the immunophenotyping experiments, total cell suspensions obtained from the bone marrow and from samples obtained on the seventh and fourteenth days after culturing in the CFU-MIX assays. The samples and negative chain controls were incubated with $5 \mu \mathrm{g}$ monoclonal antibody $/ 10^{6}$ cells per $\mathrm{ml}$, and kept from light for $20 \mathrm{~min}$ at $25^{\circ} \mathrm{C}$. After this period, the erythrocytes were lysed by adding $2 \mathrm{ml} 10 \%$ Lysing Solution (Becton Dickinson) and incubated again, sheltered from light, for $15 \mathrm{~min}$. Next, the tubes were centrifuged at $400 \mathrm{~g}$ for $10 \mathrm{~min}$, the supernatant was discarded, and the cell sediment was washed twice with PBS containing $0 \cdot 1 \%$ azide.
The sediment was resuspended in $500 \mu 11 \%$ paraformaldehyde (Sigma Chemical Co.), and the cells were acquired in a flow cytometer. Dual-parameter flow cytometry utilised a fluorescence activated cell sorter (Calibur, Becton Dickinson), equipped with an argon laser. Excitation occurred at $488 \mathrm{~nm}$ for both fluorescein isothiocyanate and phycoerythrin. Fluorescence measurements were obtained from $1 \times 10^{4}$ cells. Data were analysed using the software package Cell Quest. The results were expressed as a percentage of gated populations.

\section{Statistics}

The dependent variables are normally distributed. The results were submitted to statistical analysis (ANOVA, $P \leq 0.05$ ) using GraphPad Prism software. The data obtained in the CFU-MIX assays were analysed using three-way ANOVA and compared with each other using the Duncan test $(P \leq 0 \cdot 05)$.

\section{Results}

\section{Diet consumption, body weight and serum protein}

Mice maintained on the hypoproteic diet reduced their food consumption by up to $19 \%$, resulting in a significant reduction in protein consumption, body weight loss and a decrease in serum protein and albumin concentrations (Table 2).

\section{Blood}

The animals of the malnourished group showed leucopenia as well as a reduction in erythrocyte count, $\mathrm{Hb}$ concentration and haematocrit, and a significant reduction in the number of reticulocytes, suggesting a non-regenerative anaemia (Table 2). Significant morphological differences in the erythrocytes were not found. The administration of EPO did not normalise the haematological parameters of the malnourished animals.

\section{Serum $\mathrm{Fe}$, total $\mathrm{Fe}$-binding capacity, transferrin saturation and Fe tissue deposits}

There was no difference between the groups with respect to serum Fe concentration (control, 435.1 (SD 142.3) mg/dl; malnourished, 475.7 (SD 117.9) $\mathrm{mg} / \mathrm{dl}$ ), total Fe-binding capacity (control, $472 \cdot 7$ (SD 141.7) mg/dl; malnourished, 556.3 (SD 136.1) mg/dl) and transferrin saturation (control, 92.5 (SD 8.52)\%; malnourished, 88.2 (SD 14.58) \%). The tissue Fe reserve, evaluated by the Perls reaction, was greater in malnourished animals in the spleen (Fig. 1) and bone marrow as well as liver (data not shown).

\section{Bone marrow and spleen cells}

Animals in the malnourished group showed marrow and splenic hypoplasia (Table 2) with a pronounced reduction in the myeloid compartment (data not shown) as well as the erythroid compartment. The administration of EPO induced an increase in total cellularity as well as an increase in the erythroid component of the bone marrow and spleen in both the control and malnourished animals. This was similar between the two groups, except for the response of the erythroid compartment of the spleen after administration of 
Table 2. Protein consumption, change in body weight, serum protein, albumin concentration, total number of erythrocytes, Hb concentration, haematocrit, percentage of reticulocytes, total number of leucocytes in the blood, total number of cells and total number of erythroblasts in the bone marrow and spleen of control, control with erythropoietin (EPO), malnourished and malnourished with EPO animals

(Means values and standard deviations)

\begin{tabular}{|c|c|c|c|c|c|c|c|c|}
\hline & \multicolumn{2}{|c|}{ Control $(n 10)$} & \multicolumn{2}{|c|}{ Malnourished ( $n$ 14) } & \multicolumn{2}{|c|}{ Control + EPO $(n 6)$} & \multicolumn{2}{|c|}{$\begin{array}{c}\text { Malnourished + EPO } \\
(n 8)\end{array}$} \\
\hline & Mean & SD & Mean & SD & Mean & SD & Mean & SD \\
\hline Protein consumption ( $\mathrm{g} / \mathrm{d}$ per animal) & 0.72 & $0 \cdot 18^{a}$ & 0.18 & $0.04^{a, b}$ & 0.69 & $0 \cdot 20^{\mathrm{b}}$ & 0.20 & $0.05^{a, b}$ \\
\hline Body weight variation (\%) & 6.9 & $0.8^{\mathrm{a}}$ & $-19 \cdot 2$ & $1.4^{\mathrm{a}, \mathrm{b}}$ & $1 \cdot 3$ & $0.6^{\mathrm{b}}$ & $-22 \cdot 2$ & $1.9^{\mathrm{a}, \mathrm{b}}$ \\
\hline Serum protein $(g / l)$ & $72 \cdot 1$ & $9 \cdot 8^{\mathrm{a}}$ & 48.4 & $8 \cdot 1^{a, b}$ & $69 \cdot 3$ & $7 \cdot 8^{\mathrm{b}}$ & 44.2 & $11 \cdot 1^{\mathrm{a}, \mathrm{b}}$ \\
\hline Albumin concentration $(\mathrm{g} / \mathrm{l})$ & $42 \cdot 3$ & $6 \cdot 1^{\mathrm{a}}$ & 31.5 & $4 \cdot 1^{\mathrm{a}, \mathrm{b}}$ & $40 \cdot 1$ & $7 \cdot 2^{\mathrm{b}}$ & $29 \cdot 4$ & $5 \cdot 0^{\mathrm{a}, \mathrm{b}}$ \\
\hline Erythrocytes $\left(\times 10^{6} / \mathrm{mm}^{3}\right)$ & 6.95 & $0 \cdot 31^{a, b}$ & 3.99 & $0.41^{\mathrm{a}, \mathrm{b}}$ & $9 \cdot 14$ & $0.90^{a, b}$ & $4 \cdot 10$ & $0.35^{\mathrm{a}, \mathrm{b}}$ \\
\hline $\mathrm{Hb}(\mathrm{g} / \mathrm{l})$ & $12 \cdot 8$ & $1.01^{a, b}$ & 6.9 & $0.40^{\mathrm{a}, \mathrm{b}}$ & $18 \cdot 6$ & $1 \cdot 62^{\mathrm{a}, \mathrm{b}}$ & $7 \cdot 2$ & $0.77^{\mathrm{a}, \mathrm{b}}$ \\
\hline Haematocrit (\%) & $36 \cdot 2$ & $2 \cdot 15^{a, b}$ & $19 \cdot 8$ & $2 \cdot 85^{a, b}$ & $54 \cdot 2$ & $5 \cdot 04^{a, b}$ & 23.5 & $3 \cdot 01^{a, b}$ \\
\hline Reticulocytes (\%) & 6.98 & $0.87^{\mathrm{a}, \mathrm{b}}$ & $1 \cdot 20$ & $.21^{\mathrm{a}, \mathrm{b}}$ & $12 \cdot 73$ & $1 \cdot 0^{\mathrm{a}, \mathrm{b}}$ & 0.21 & $.57^{\mathrm{a}, \mathrm{b}}$ \\
\hline Leukocytes $\left(/ \mathrm{mm}^{3}\right)$ & 3868 & $225^{a}$ & 1463 & $221^{a, b}$ & 4138 & $618^{\mathrm{b}}$ & 1442 & $15 \cdot 8^{a, b}$ \\
\hline Bone marrow total cells $\left(\times 10^{7} / \mathrm{ml}\right)$ & 0.87 & $0.07^{\mathrm{a}}$ & 0.58 & $0.04^{a, b}$ & 1.08 & $0.06^{\mathrm{b}}$ & 0.63 & $0.04^{\mathrm{a}, \mathrm{b}}$ \\
\hline Bone marrow total erythroblasts $\left(\times 10^{5} / \mathrm{ml}\right)$ & $10 \cdot 23$ & $1 \cdot 23^{a, b}$ & 1.72 & $0.3^{a, b, c}$ & $28 \cdot 25$ & $.57^{\mathrm{a}, \mathrm{b}}$ & 5.49 & $1.01^{\mathrm{a}, \mathrm{b}, \mathrm{c}}$ \\
\hline Spleen total cells $\left(\times 10^{7} / \mathrm{ml}\right)$ & 0.83 & $0.07^{\mathrm{a}}$ & 0.49 & $0.05^{a, b}$ & 1.02 & $0 \cdot 20^{\mathrm{b}}$ & 0.51 & $0.04^{\mathrm{a}, \mathrm{b}}$ \\
\hline Spleen total erythroblasts $\left(\times 10^{5} / \mathrm{ml}\right)$ & 5.09 & $0.64^{a, b}$ & $1 \cdot 21$ & $0.34^{\mathrm{a}, \mathrm{b}}$ & 17.43 & $4.09^{\mathrm{a}, \mathrm{b}}$ & 3.0 & $0.9^{\mathrm{b}}$ \\
\hline
\end{tabular}

For details of diets and procedures, see pp. 308-309.

${ }^{a}$ Mean values were significantly different between the control group without EPO and other groups $(P \leq 0.05)$.

${ }^{\mathrm{b}}$ Mean values were significantly different between the control group with EPO and other groups $(P \leq 0.05)$.

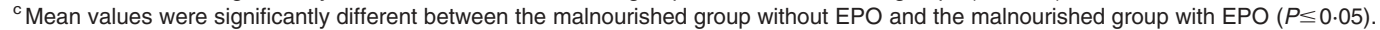

EPO, which was smaller in the malnourished animals. The relationship of granulocytic to erythroid precursor cells in the malnourished animals was significantly smaller $(P \leq$ $0,01)$, independent of whether the animals had or had not received EPO (data not shown), confirming the depletion of the erythrocytic compartment.

\section{Determination of erythropoietin}

No difference was found between the control and malnourished animals with respect to the concentration of circulating erythropoietin (control, 780.9 (SD 295.1) pg/ml; malnourished, 848.4 (SD $205.9 \mathrm{pg} / \mathrm{ml})$.

\section{Mixed colony-forming unit, erythroid burst-forming unit} and erythroid colony-forming unit

Results were expressed the number of granulocyte-macrophage colony-forming units, erythroid burst-forming units, erythroid colony-forming units and CFU-MIX in the clono- genic assays using total cells from the bone marrow of the control and malnourished animals. Differential total cell counts were monitored, and counts were carried out on cytocentrifuge smears prepared. In the clonogenic assays, the number of CFU-MIX was significantly lower than in cultures carried out with the cells of malnourished animals, demonstrating the existence of a smaller number of primitive precursors in the bone marrow of malnourished mice. Furthermore, neither erythroid burst-forming units nor erythroid colonyforming units were found (Table 3).

Flow cytometric profiling of cells in the bone marrow, spleen and CFU-MIX culture

Immunophenotypic analysis of the marrow and spleen populations applying AcMO, CD45, CD117, Ter-119, CD71 and CD2 as markers confirmed the depletion of erythroid precursors in malnourished animals. We found an reduced expression of the $\mathrm{CD} 45^{+}$cell population of malnourished animals, especially the population of immature cells that were $\mathrm{CD} 45^{\text {low }}$. This depletion
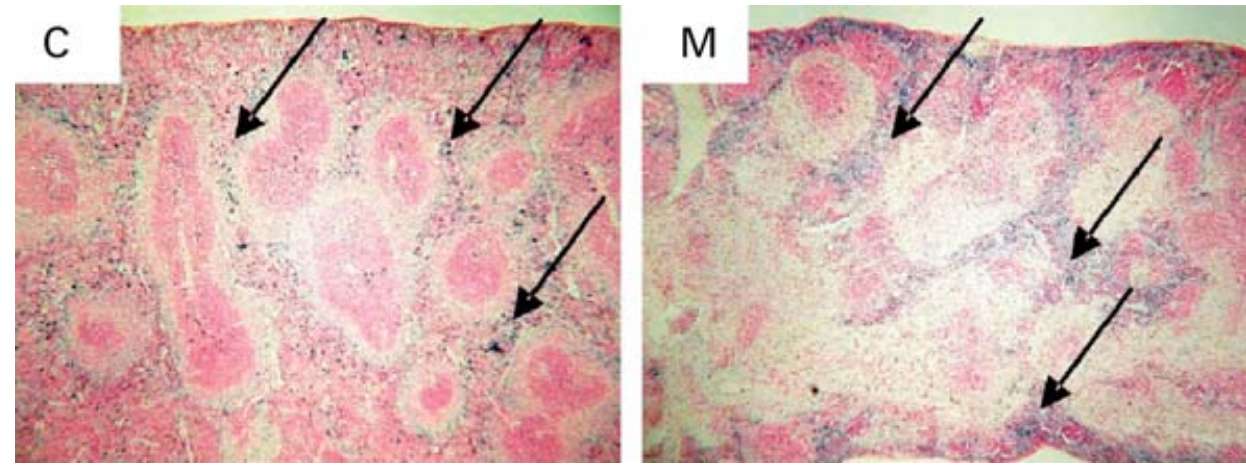

Fig. 1. Spleen sections stained by Perls method to evaluate tissue Fe in the control (C) and malnourished (M) groups. Arrows indicate Fe as blue points in red pulp ( $\times 165)$. For details of diets and procedures, see pp. 308-309. 
Table 3. Number of granulocyte-macrophage colony-forming units (CFU-GM), erythroid burst-forming units (BFU-E), erythroid colony-forming units (CFU-E), and mixed colony-forming units (CFU-MIX) in the clonogenic assays using total cells in the bone marrow of control and malnourished animals

(Representative experiment of three similar experiments)

\begin{tabular}{|c|c|c|c|c|c|c|}
\hline & \multicolumn{2}{|c|}{$7 \mathrm{~d}\left(\mathrm{CFU} \times 10^{3} / \mathrm{ml}\right)$} & \multicolumn{2}{|c|}{$14 \mathrm{~d}\left(\mathrm{CFU} \times 10^{3} / \mathrm{ml}\right)$} & \multicolumn{2}{|c|}{$21 \mathrm{~d}\left(\mathrm{CFU} \times 10^{3} / \mathrm{ml}\right)$} \\
\hline & Control & Malnourished & Control & Malnourished & Control & Malnourished \\
\hline CFU-GM & 142 & $128^{*}$ & 241 & $145^{\star}$ & 273 & $133^{*}$ \\
\hline BFU-E/CFU-E & 28 & $0^{*}$ & 7 & $0^{*}$ & 4 & $0^{*}$ \\
\hline CFU-MIX & 23 & $0^{*}$ & 12 & $0^{*}$ & 4 & $0^{*}$ \\
\hline
\end{tabular}

For details of diets and procedures, see p.00. Cultures in semisolid medium were incubated for $21 \mathrm{~d}$ at $36.8^{\circ} \mathrm{C}$ in a humid atmosphere containing $5 \% \mathrm{CO}_{2}$ and were evaluated on the seventh, fourteenth and twenty-first days after culturing using an inverted microscope.

* Mean values were significantly different between the experimental and control groups $(P \leq 0 \cdot 05)$.

in primitive cells was confirmed by the lower expression of CD117 (c-kit receptor; Fig. 2). The population that expressed Ter-119 and CD71 (transferrin receptor) was also found to be considerably reduced (Fig. 3). Bone marrow cells of control animals were found to express two populations-CD71 ${ }^{\text {high }}$ (more mature population) and $\mathrm{CD} 71^{\text {low }}$ (less mature population) whereas malnourished animals presented a small percentage of CD71 ${ }^{\text {low }}$ cells and did not show a CD71 ${ }^{\text {high }}$ population. As the CD71 antigen is also expressed in lymphoid cells, we used CD71/CD2 double-marking in order to separate and quantify the erythroid and lymphoid populations.

The results of the clonogenic assays and the immunophenotypic profile of cells obtained from the spleen (data not shown) were similar to those obtained when using bone marrow cells.

\section{Discussion}

The present study indicates that protein malnutrition produces normochromic, normocytic anaemia, with a significant reduction in reticulocyte and alterations in bone marrow and spleen erythropoiesis. The anaemia found does not show characteristics of either Fe-deficiency anaemia or anaemia that is secondary to chronic disease.

The control group received an adequate protein diet, and the test group received a protein-deficient diet. The deficient group had, however, a markedly lower feed intake and experienced about a $20 \%$ loss of body weight. Thus, in the study, we sought to compensate this effect by preparing a diet exceeding the recommendations of the American Institute of Nutrition AIN-93 (Reeves et al. 1993). As a result, even though the animals ingested a lower amount of food, the diet we prepared met the minimum nutrient requirements for adult mice (Reeves et al. 1993). As the minimum daily amounts of nutrients were ingested by the animals in the malnourished group, we can conclude that the changes observed in our experimental model were mainly the result of the reduction in protein and energy intake compared with the control group. Animals belonging to the malnourished group lost $25 \%$ of their initial weight in a period of $14-16 \mathrm{~d}$ after the introduction of the hypoproteic diet.

Haemopoietic tissue, like all tissues that have a high rate of renewal and cellular proliferation, presents a high demand for nutrients. The sheer need for protein for the process of haemopoiesis could in itself justify the occurrence of anaemia and leucopenia, which are frequently encountered in malnourished human subjects. According to Vilter (1975), children with typical protein-energy malnutrition have a normochromic, normocytic anaemia, with $\mathrm{Hb}$ levels that lie between 8 and $10 \mathrm{~g} / \mathrm{dl}$ and normal medullary erythropoiesis, or a discretely hypoplastic marrow with fatty infiltration.

The lack of Fe has been considered to be the main cause of anaemia in malnourishment (Finch, 1975). Other authors have, however, found normal $\mathrm{Fe}$ serum levels with an increase in transferrin saturation (Ramdath \& Golden, 1989) and normal serum ferritin levels, the bone marrow presenting normal or elevated $\mathrm{Fe}$ deposits. Liver biopsies obtained post mortem from individuals suffering from marasmus have demonstrated high levels of Fe (Mclarem et al. 1968; Waterlow, 1996). Fondu et al. (1978) concluded that the anaemia was caused by a reduction in the mean life of the erythrocytes, suggesting that an increase in erythrocyte fragility was the result of a decrease in Se and vitamin E ingestion. Furthermore, these same authors suggested that among the causes of anaemia in protein-energy malnutrition was an adaptation of the organism to the reduction in the demand for $\mathrm{O}$ and also to chronic infections, which are frequently present.

Reissman (1964) reported anaemia in malnourished rats and suggested as a mechanism a slow-down in protein synthesis in erythroid cells and/or a reduction in erythropoietin synthesis. Aschkenasy (1957) observed, in protein malnutrition, the presence of anaemia and leucopenia, and erythroid marrow hyperplasia without a simultaneous elevation in erythropoietin concentration. Anaemia, in experimental malnutrition, presents a decrease in Fe incorporation and in the number of reticulocytes (Fried et al. 1978) and furthermore an interruption in the maturation process of erythroblasts. Studies (Fried \& Gurney, 1965; Seifter et al. 1971; Aschkenasy, 1975) have demonstrated that, in rats, a fall in erythropoietin occurred due to the reduced ingestion of protein, in opposition to the results obtained in our study. Serum concentrations of erythropoietin were found to be both increased (Macdougall et al. 1982; el-Nawawy et al. 2002) and decreased (Reissman, 1964; Catchatourian et al. 1980) in protein malnutrition and protein-energy malnutrition, the reduction being attributed to a decrease in the speed of $\mathrm{O}$ use by the tissues.

The present data suggest that the anaemia found in adult mice submitted to protein deficiency was not due to Fe deficiency, as the serum $\mathrm{Fe}$ concentration of these animals was found to 
C

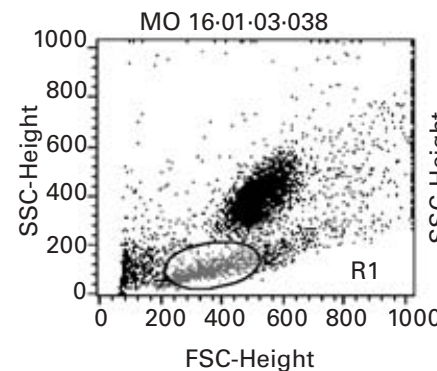

C
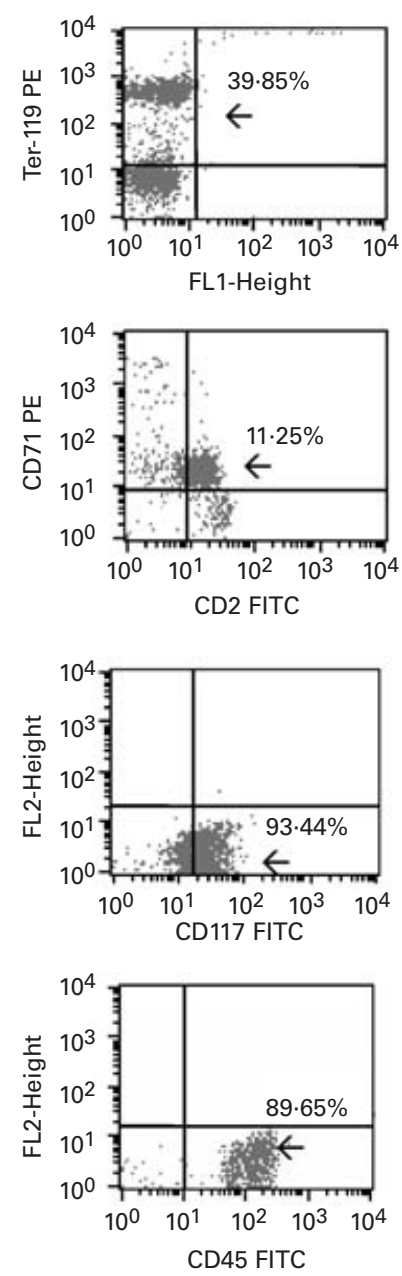

$\mathrm{M}$

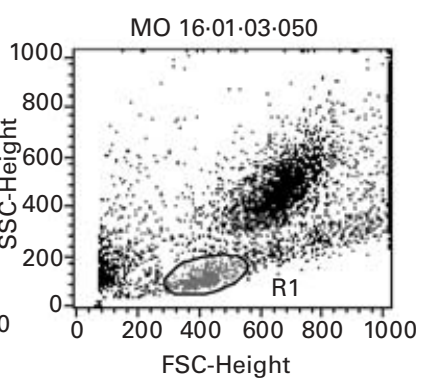

M
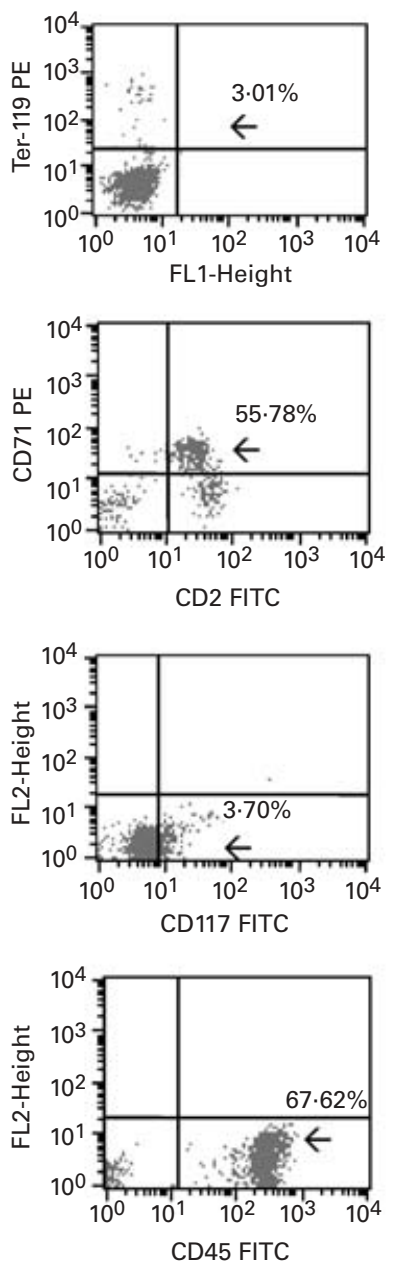

Fig. 2. Immunophenotyping of cells in the bone marrow of control (C) and malnourished $(\mathrm{M})$ animals. The results were expressed in a dot plot: (gate R1) referent to the expression of Ter-119, CD71, CD2, CD117 and CD45. For details of diets and procedures, see pp. 308-309. FITC, fluorescein isothiocyanate; PE, phycoerythrin; SSC, side scatter; FSC, forward scatter.

be high, as were the levels of transferrin saturation and ferritin concentration in the bone marrow, liver and spleen. The present results indicate that the response of animals in the control group to the administration of erythropoietin was significantly higher than that of malnourished animals. The morphological analysis of the bone marrow and of the spleen revealed, in malnourished animals, the presence of lympho-haemopoietic hypoplasia, especially of the myeloid compartment, with an
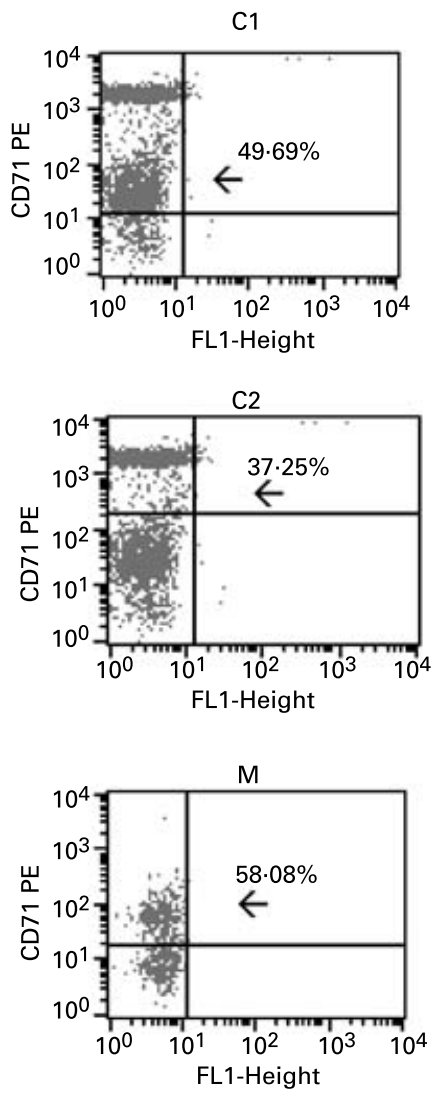

Fig. 3. Immunophenotyping of cells in the bone marrow of control $(C)$ and malnourished (M) animals. The results were expressed in a dot plot: (gate R1) referent to the expression of CD71. Immunophenotyping shows positivity for the control group, which permits the distinction between a CD$71^{\text {low }}$ population and a CD-71 ${ }^{\text {hi }}$ population, one of low intensity $\left(C_{1}\right)$ and one of high intensity $\left(\mathrm{C}_{2}\right)$, respectively, whereas the malnourished group (M) exhibited only a CD-71 low population, with low intensity. For details of diets and procedures, see pp. 308-309. PE, phycoerythrin.

emphasis on the erythroid compartment. These findings were corroborated by the results of CFU-MIX, erythroid burst-forming unit growth and immunophenotypic analysis. The immunophenotypic analysis of marrow and spleen population demonstrated a depletion of the erythroid population, indicating a reduction in the number of erythroid progenitors in malnourished animals. Hypoproliferative anaemia is associated with a reduction in the number of erythroid precursors, which can be caused by conditions such as aplastic anaemia, myelofibrosis and infiltrative processes in the bone marrow. As has already been reported in previous studies (Fried et al. 1957; Borelli et al. 1995), we found severe splenic and marrow hypoplasia with severe structural alterations in the haemopoiesis-inducing microenvironment (Vituri et al. 2000).

According to Stohlman (1972), bone marrow atrophy can result from abnormalities of stem cells or defects in stromal cells, which would alter the haemopoietic microenvironment. Genetically modified $\left(\mathrm{W} / \mathrm{W}^{\mathrm{w}}\right)$ mice possess an alteration in the proto-oncogene $c$-kit, a receptor with tyrosine-kinase activity for stem cell factor (a growth factor for stem cells). Mice that possess an alteration known as Steel $\left(\mathrm{SL} / \mathrm{SL}^{\mathrm{d}}\right)$ do not express a binding c-kit receptor (CD117), which is the 
receptor for stem cell growth factor, and furthermore show an alteration in the stroma of the marrow matrix (Shadduck, 1995), as well as anaemia. In the present study, we found a reduction in the $\mathrm{CD}_{11} 7^{+}$population among the bone marrow and spleen cells of malnourished mice. The anaemia, leucopenia and bone marrow atrophy found in mice subjected to protein malnutrition suggest a decrease in the proliferative capability of progenitor cells, because the reduction in the marrow compartment was not due to an increase in the efflux of cells into the peripheral blood or to apoptotic processes (data not shown).

All these results suggest that, in essence, this anaemia is not caused by Fe deficiency or erythropoietin deficiency, but is in fact a result of ineffective erythropoiesis.

\section{Acknowledgements}

The authors thank Dr Marcelo Macedo Rogero for his suggestions. This investigation was supported by grants from the Fundação de Amparo a Pesquisa do Estado de São Paulo FAPESP (03/07 322-1), and from the Conselho Nacional de Pesquisa (CNPq), Brazil.

\section{References}

Akman M, Cebeci D, Okur V, Angin H, Abali O \& Akman AC (2004) The effects of iron deficiency on infants' developmental test performance. Acta Paediatr 93, 1391-1396.

Aschkenasy A (1957) On the pathogenesis of anemias and leukopenias induced by dietary protein deficiency. Am J Clin Nutr 5, $14-25$.

Aschkenasy A (1975) Effect of a protein-free diet on lymph node and spleen cell response in vivo to blastogenic stimulants. Nature 254, $63-65$.

Borelli P, Mariano M \& Borojevic R (1995) Protein malnutrition: effect on myeloid cell production and mobilization into inflammatory reactions in mice. Nutr Res 15, 1477-1485.

Buitron D, Hurtig AK \& San Sebastian M (2004) Nutritional status of Naporuna children under five in the Amazon region of Ecuador. Rev Panam Salud Publica 15, 151-159.

Catchatourian R, Eckerling G \& Fried W (1980) Effect of short-term protein deprivation on hemopoietic functions of healthy volunteers. Blood 55, 625-628.

Chimelli L, Bello AR \& Scaravilli F (1994) Development of cortical fibres into the gracile nucleus of the rat: an ultrastructural study. Dev Neurosci 16, 260-266.

Dacie JV \& Lewis SM (1995) Practical Haematology. Churchill Livingstone: Edinburgh, UK.

Doumas BT, Watson WA \& Biggs HG (1971) Albumin standards and the measurement of serum albumin with bromocresol green. Clin Chim Acta 31, 87-96.

el-Nawawy A, Barakat S, Elwalily T, Abdel-Moneim Deghady A \& Hussein M (2002) Evaluation of erythropoiesis in protein energy malnutrition. East Mediterr Health J 8, 281-289.

Finch CA (1975) Erythropoiesis in protein-calorie malnutrition. In Protein-Calorie Malnutrition, pp. 247-256 [RE Olson, editor]. New York: Academic Press.

Fondu P, Hariga-Muller C, Mozes N, Neve J, Van Steirteghem A \& Mandelbaum IM (1978) Protein-energy malnutrition and anemia in Kivi. Am J Clin Nutr 31, 46-56.

Fried W, Goldwasser E, Jacobson LO \& Plzak LF (1957) Studies on erythropoiesis. III. Factors controlling erythropoietin production. Proc Soc Exp Biol Med 94, 237-241.
Fried W \& Gurney CW (1965) Erythropoietic effect of plasma from mice receiving testosterone. Nature 206, 1160-1161.

Fried W, Shapiro S, Barone J \& Anagnost A (1978) Effect of protein deprivation on hematopoietic stem cells and on peripheral blood counts. J Lab Clin Med 92, 303-310.

Gasche C, Lomer MC, Cavill I \& Weiss G (2004) Iron, anaemia, and inflammatory bowel diseases. Gut 53, 1190-1197.

Gibson RS (2004) Strategies for preventing micronutrient deficiencies in developing countries. Asia Pac J Clin Nutr 13, Suppl., S23.

Goodwin JF, Murphy B \& Guillemette M (1966) Direct measurement of serum iron and binding capacity. Clin Chem 12, 47-57.

Gornall AG, Bardawill CJ \& David MM (1949) Determination of serum proteins by means of the biuret reactions. J Biol Chem 177, 751 .

Heyworth CM \& Spooncer E (1993) In vitro clonal assays for murine multipotential and lineage restricted myeloid progenitor cells. In Haemopoiesis: A Practical Approach, pp. 37-48 [G Molineux and NG Testa, editors]. Practical Approach Series. New York: Oxford University Press.

Khosrof-Ben Jaafar S, Gharbi N, El Fazaa S, Beji C, Farhat A, Cherif S, Haddad S \& Kamoun A (2004) Iron deficiency anemia and protein-energetic status in woman from 15 to 49 years old in Tunisia. Tunis Med 82, 263-270.

Lozoff B, Jimenez E \& Wolf AW (1991) Long-term developmental outcome of infants with iron deficiency. $N$ Engl J Med 325, 687-694.

Macdougall LG, Moodley G, Eyberg C \& Quirck M (1982) Mechanisms of anemia in protein-energy malnutrition in Johannesburg. Am J Clin Nutr 35, 229-235.

Mclarem DS, Fariz R \& Zeckian B (1968) The liver during recovery from protein-calorie malnutrition. J Trop Med Hyg 71, 271-281.

Mehta BC (2004) Iron deficiency amongst nursing students. Indian J Med Sci 58, 389-393.

Moretti R, Torre P, Antonello RM, Cattaruzza T, Cazzato G \& Bava A (2004) Vitamin B12 and folate depletion in cognition: a review. Neurol India 52, 310-318.

Ramdath DD \& Golden MHN (1989) Non-hematological aspects of iron nutrition. Nutr Res Rev 2, 29-50.

Reeves PG, Nielsen FH \& Fahey GC (1993) AIN-93 purified diets for laboratory rodents: final report of the American Institute of Nutrition Ad Hoc Writing Committee on the Reformulation of the Ain76a Rodent. Diet J Nutr 123, 1939-1951.

Reissman KR (1964) Protein metabolism and erythropoiesis. II Erythropoietin formation and erythroid responsiveness in protein deprived rats. Blood 146, 146-153.

Rodkey FL (1965) Direct spectrophotometric determination of albumin in human serum. Clin Chem 1, 478-487.

Rosai J (editor) (1996) Special techniques. In Ackerman's Surgical Pathology, 8th ed., pp. 29-62. St Louis: Mosby.

Seifter E, Rettura G, Reissman D, Kambosos D \& Levenson SM (1971) Nutritional response to feeding L-phenyllactic, shikimic and D-quinic acids in weanling rats. J Nutr 101, 747-754.

Shadduck RK (1995) Aplastic anemia. In Williams' Hematology, 5th ed., pp. 238-248 [E Beutler, MA Lichtman, BS Coller and TJ Kipps, editors]. New York: McGraw-Hill.

Silver DF \& Piver MS (1999) Effects of recombinant human erythropoietin on the antitumor effect of cisplatin in SCID mice bearing human ovarian cancer:lpossible oxygen effect. Gynecol Oncol 73, 280-284.

Stenvinkel P (2003) Anaemia and inflammation: what are the implications for the nephrologist? Nephrol. Dial Transplant 18, Suppl. 8, $17-22$.

Stohlman F (1972) Aplastic anemia. Blood 40, 282-286.

Stoltzfus RJ, Chway HM, Montresor A, Tielsch JM, Jape JK, Albonico M \& Savioli L (2004) Low dose daily iron supplementation improves iron status and appetite but not anemia, whereas quarterly anthelminthic treatment improves 
growth, appetite and anemia in Zanzibari preschool children. $J$ Nutr 134, 348-356.

Villalpando S, Latulippe ME, Rosas G, Irurita MJ, Picciano MF \& O'Connor DL (2003) Milk folate but not milk iron concentrations may be inadequate for some infants in a rural farming community in San Mateo, Capulhuac, Mexico. Am J Clin Nutr 78, 782-789.

Vilter RW (1975) The anaemia. In Protein-Calorie Malnutrition, pp. 257-261 [RE Olson, editor]. New York: Academic Press.
Vituri CL, Alvarez-Silva M, Trentin AG \& Borelli P (2000) Alterations in proteins of bone marrow extracellular matrix in undernourished mice. Braz J Med Biol Res 33, 889-895.

Ward PG (1963) A micro-Kjeldahl procedure for field use. J Med Lab Technol 20, 191-195.

Waterlow JC (1996) Malnutrición proteico-energetica. Washington: Organización Panamericana de la Salud.

Yip R (1996) Prevention and control of iron deficiency in developing countries. Curr Issues Public Health 2, 253-263. 